\title{
THE CORPORATE SOCIAL RESPONSIBILITY MOVEMENT AND LAW'S EMPIRE: IS THERE A CONFLICT?
}

\author{
Professor Irene Lynch Fannon, Faculty and Department of Law, \\ University College Cork*
}

\begin{abstract}
At the heart of corporate governance and social responsibility discourse is recognition of the fact that the modern corporation is primarily governed by the profit maximisation imperative coupled with moral and ethical concerns that such a limited imperative drives the actions of large and wealthy corporations which have the ability to act in influential and significant ways, shaping how our social world is experienced. The actions of the corporation and its management will have a wide sphere of impact over all of its stakeholders whether these are employees, shareholders, consumers or the community in which the corporation is located. As globalisation has become central to the way we think it is also clear that "community" has an ever expanding meaning which may include workers and communities living very far away from Corporate $H Q$. In recent years academic commentators have become increasingly concerned about the emphasis on what can be called short-term profit maximisation and the perception that this extremist interpretation of the profit imperative results in morally and ethically unacceptable outcomes. ${ }^{1}$ Hence demands for more corporate social responsibility.

Following Cadbury's ${ }^{2}$ classification of corporate social responsibility into three distinct areas, this paper will argue that once the legally regulated tier is left aside corporate responsibility can become so nebulous as to be relatively meaningless. The argument is not that corporations should not be required to act in socially responsible ways but that unless supported by regulation, which either demands high standards, or at the very least incentivises the attainment of such
\end{abstract}

* This paper was first delivered at a conference at Queens University Belfast in October 2005. My thanks are due to the Institute for Accountable Governance for organising the event and inviting me to present. Thanks are due to Kieran Walsh BCL, BL who provided research assistance for this paper. Finally thanks are due to Professor Sally Wheeler for her intellectual interest and patience.

1 Mitchell. Corporate Irresponsibility: America's Newest Export, (2001). Mitchell. Corporate Irresponsibility: America's Newest Export 70 George Washington Law Review. 2002. David Millon. "Why is Corporate Management Obsessed with Quarterly Earnings and What Should be Done about It?" 2002. George Washington Law Review 70: 890.

2 Cadbury. The Company Chairman (1990) 
standards such initiatives are doomed to failure. The paper will illustrate by reference to various chosen cases that law's discourse has already signposted ways to consider and resolve corporate governance problems in the broader social responsibility context. ${ }^{3}$ It will also illustrate how corporate responsibility can and must be supported by legal measures. Secondly, this paper will consider the potential conflict between an emphasis on corporate social responsibility and the regulatory approach. ${ }^{4}$ Finally, this paper will place the current interest in corporate social responsibility within the broader debate on the relationship between law and nonlegally enforceable norms and will present some reflections on the norm debate arising from this consideration of the CSR movement.

\section{Introduction}

At the heart of corporate governance and social responsibility discourse is recognition of the fact that the modern corporation is primarily governed by the profit maximisation imperative coupled with moral and ethical concerns that such a limited imperative drives the actions of large and wealthy corporations which have the ability to act in influential and significant ways, shaping how our social world is experienced. The actions of the corporation and its management will have a wide sphere of impact over all of its stakeholders whether these are employees, shareholders, consumers or the community in which the corporation is located. As globalisation has become central to the way we think it is also clear that "community" has an ever expanding meaning which may include workers and communities living very far away from Corporate HQ. In recent years academic commentators have become increasingly concerned about the emphasis on what can be called short-term profit maximisation and the perception that this extremist interpretation of the profit imperative results in morally and ethically unacceptable outcomes. ${ }^{5}$ Hence demands for more corporate social responsibility.

Following Cadbury's ${ }^{6}$ classification of corporate social responsibility into three distinct areas, this paper will argue that once the legally regulated tier is left aside corporate responsibility becomes so nebulous as to be relatively meaningless. The argument is not that corporations should not be required to

3 United States of America v Beech-Nut Corporation and Niels L. Hoyvald 925 F. 2d. 604. In re: A.H. Robins Company Inc. Debtor Alexia Anderson et al 42 F. $3 \mathrm{~d}$. 870 and $R$ v $P \& O$ Ferries (1990) 93 Cr. App. Rep. 72.

4 Commission of the European Communities COM (2001) 366. Corporate Social Responsibility. Social Committee and the Committee of the Regions on Promoting Core Labour Standards and improving social governance in the context of globalisation. Com (2001) 416 [18.7.2001].

5 Mitchell Corporate Irresponsibility: America's Newest Export, (2001). "Corporate Irresponsibility: America's Newest Export" 2002. 70 George Washington Law Review. Millon, "Why is Corporate Management Obsessed with Quarterly Earnings and What Should be Done about It?" (2002) 70 George Washington Law Review 890.

6 Cadbury. The Company Chairman (1990) 
act in socially responsible ways but that unless supported by regulation, which either demands high standards, or at the very least incentivises the attainment of such standards such initiatives are doomed to failure. The paper will illustrate by reference to various chosen cases that law's discourse has already signposted ways to consider and resolve corporate governance problems in the broader social responsibility context. ${ }^{7}$ Secondly, this paper will consider the potential conflict between an emphasis on corporate social responsibility and the regulatory approach. ${ }^{8}$ Finally, this paper will consider the implications for the broader debate on the relationship between law and non-legally enforceable norms raised by this analysis of the corporate social responsibility movement. ${ }^{9}$

The paper is divided into three parts, the first will consider what we mean by corporate social responsibility. The second will consider some cases and materials within the legal domain which have illustrated that there has always been a clear understanding that corporations should and do act beyond a minimum level of legal compliance and that corporate law and theory clearly supports and understands this idea. In particular over considerable periods of time chancery courts on both sides of the Atlantic have resolved potential conflicts between shareholder primacy and welfare, or indeed its less attractive version, the shareholder wealth maximisation principle ${ }^{10}$ on the one hand and socially responsible actions on the other. The third part considers how the modern emphasis on corporate social responsibility fits with the more theoretical analysis regarding norms and behaviour generally and in doing so highlights some difficulties with the voluntary approach which are a source of concern, asking in particular how meaningful an emphasis on voluntary behaviour actually is.

7 United States of America v Beech-Nut Corporation and Niels L. Hoyvald 925 F. 2d. 604. In re: A.H. Robins Company Inc. Debtor Alexia Anderson et al 42 F. 3d. 870 and R v P\& O Ferries (1990) 93 Cr. App. Rep. 72.

8 Commission of the European Communities COM (2001) 366. Corporate Social Responsibility. Social Committee and the Committee of the Regions on Promoting Core Labour Standards And Improving Social Governance In The Context Of Globalisation. Com (2001) 416 [18.7.2001].

9 See "Law, Economics and Norms" (1996) 144 University of Pennsylvania Law Review 1643 and "Social Norms, Social Meaning and the Economic Analysis of Law" (1998) 27 Journal of Legal Studies, 537. See further "Norms and Corporate Law" (2001) 149 University of Pennsylvania Law Review.

10 Millon in his article mentioned at n.2 supra develops the distinction between the shareholder primacy principle and the shareholder wealth maximisation principle, the latter he argues is an aberrant version of the former principle, not necessarily required under corporate law principles, but driven more by an emphasis on short termism, which in turn is driven by an over emphasis on the importance of the capital markets as a corporate governance device. In consideration of the case law it is clear that even though the principle of shareholder primacy is all important as the driving principle as far as stakeholder distribution, it is clear that the courts do not, and have never, required managers to sacrifice all other stakeholder well being at the altar of short-termism. Millon's article provides a lucid theoretical distinction between these principles. 


\section{Part I: What is meant by CSR?}

From a lawyer's perspective the current fashionable interest in CSR leads not to clear answers as to what is meant but to many questions about motivation, purpose and so on. A number of large consulting firms have formed CSR units to advise their corporate clients on how to act in more socially responsible ways. Justifications for CSR range from reputational benefits accruing to the company to financially beneficial outcomes. However it is hard to escape the suspicion that sometimes and perhaps at best (because there may be more worrisome motivations, described below) corporate interest in overt CSR matters is a movement fitting more into the PR or image building side of things than hard core financial accounting. What is puzzling about the CSR movement is what lies beneath this "new" idea that a company should act in socially accountable and responsible ways. In fact companies and their managers have always been accountable to the broader society in which they are placed and have always been not only required, but also, in many cases, positively motivated to act responsibly. The idea is not new, but it is argued here that what is new about CSR is the attempt to move the forum of discourse about accountability and responsibility away from law's empire ${ }^{11}$ or dominion. The question raised in this article is why has this happened and what are the implications for regulation of corporate activities.

CSR is normally considered as influencing the corporation's actions in relation to the following areas of activity: The Workplace and Employee Relations; The Community in which the corporation is located; Supply Chain Management; Customer Relations; Environmental concerns and Sustainable Development.

Typically, in the corporate and accounting context, different CSR indices are measured such as input measures, for example staff turnover, absences and staff grievances and output measures such as staff satisfaction surveys, and perception measures for staff in the workplace area. Community outputs measure employee voluntarism in the community and support for this. Concern with suppliers could include as an input measurement the average creditor days, the number of successful legal actions taken and output could include quality of supply and of the supply chain. This kind of CSR reporting is becoming an integral part of many businesses. ${ }^{12}$

What is unclear about the classification of many of these initiatives as CSR initiatives is the relationship between these actions and actions which are legally required or which at the very least facilitate compliance with legal standards. The articulation of the close connection is lacking within the CSR movement. In relation to the example provided above relating to creditors, any contract will provide for timely payment, any missed payment will trigger legal consequences ${ }^{13}$ so it is unclear how such compliant behaviour is

11 Dworkin. Law's Empire (1988).

12 Hill. "How Finance can help move CSR up the Agenda" Finance Magazine, September 2005. See also for a flavour of the corporate/accounting approach www.deloitte.com. Accessed January 12, 2007.

13 Note that under s.213(e) of the 1963 Companies Act, any creditor owed more than $\mathbf{x}$ can petition the court for liquidation if demand letters are not met. The time 
classified as responsible in the same way as measures taken by the corporation to support voluntary activity within the community. Similarly in the workplace much of what is given as examples in the CSR literature actually reflects the need to comply with legal standards or at the very least to show that the corporation is doing what it can to comply with legal standards. Hill proffers the example of gender bias in the supermarket retail sector where there is a high proportion of women employed at lower levels compared with the proportion of women employed as managers. CSR, it is argued, can provide data on employment levels and on improvements to indicate the corporation is serious about being socially responsible. In reality however, any corporation involved in the retail sector or indeed in any other sector where there is a gender imbalance between the lower grades of workers and the higher grades of workers would be advised to do this kind of data collection to protect themselves against potential litigation of the kind which occurred in the US between the EEOC and the department store chain Sears Roebuck. ${ }^{14}$

CSR has benefited in recent times from the attention of the European Commission. In considering the publications on this area emanating from the Directorate General of Employment and Social Affairs ${ }^{15}$ and other sections including the Directorate General for Enterprise and the Information Society, it is clear that the global context is extremely significant in relation to European style CSR. The attempt to ensure socially responsible actions in supply chain management, movement of capital and other areas of corporate activity across the globe seems to be the main focus of the EU CSR documents. The emphasis on labour rights and sustainable development in environmental terms is also very clear.

"Within the company, socially responsible practises primarily involve employees and relate to issues such as investing in human capital, health and safety and managing change, while environmentally responsible practices relate mainly to the management of natural resources used in production." 16

Management of industrial change is also a key issue.

frame is surprisingly short as is the threshold amount owed which entitles any creditor to standing to petition to liquidate a company. Of course the application of the short demand time is not reflected in practice, nevertheless it is surprising that compliance with payment of creditors would be considered to be a 'socially responsible' action rather than a legally required one.

14 EEOC v Sears, Roebuck \& Co. 628 F. Supp. 1264 (N. D. Ill 1986) (Sears II).

15 DG Employment and Social Affairs: Green Paper: Promoting a European Framework for Corporate Social Responsibility. July 2001. This paper is based on COM (2001) 366 final. See also ABC of the Main Instruments of Corporate Social Responsibility, DG Employment and Social Affairs. 2004, in particular pages 32-35 where Directives and other national legislative instruments in this area are listed. Both these documents can be down loaded from the EU website www.europa.eu.int. Accessed on 4 Oct. 2005. In addition the Multi-Stakeholder Forum established in 2004 has pursued and active agenda with a recent meeting and agenda setting exercise in December 2006. http://ec.europa.eu/enterprise/csr/ forum_2006_index.htm. Accessed 14 Jan. 2007.

$16 \mathrm{ABC}$ of the Main Instruments of Corporate Social Responsibility, DG Employment And Social Affairs. 2004, Para.2:1 forward. 
"Recent high-profile announcements of large-scale redundancies have put the spotlight on the way firms interact with their employees in such situations, and management of change is one of the key aspects of corporate social responsibility that the Green Paper discusses." 17

As a policy initiative at EU level the emphasis on CSR is also tied in with the objectives of the Lisbon Agenda initiated in 2000 and revised at its mid-term point in 2005. Questions must be asked about the success of these initiatives at this point in time when the Lisbon Agenda itself is acknowledged to be in serious difficulties. 18 This document notes the difference between legal compliance and voluntary socially responsible actions and encourages companies to "go beyond compliance" noting that there is a relationship between proactive actions and improved competitiveness, an assertion that is not proved by the document. However importantly it is noted that

"Corporate Social responsibility should nevertheless not be seen as a substitute to regulation or legislation concerning social rights and environmental standards, including the development of new appropriate legislation. In countries where such regulations do not exist efforts should focus on putting the proper regulatory or legislative framework in place in order to define a level playing field on the basis of which socially responsible actions can be developed." ${ }^{19}$

CSR has also caught the populist imagination and is very much seen as the way forward by those interested in issues ranging from the perceived threat of globalisation, exploitation of workers and communities in developing economies, to protection of the supply chain for many consumable goods including food products such as coffee etc.

Although areas of concern can thus range from companies acting nicely in their own neighbourhood to companies acting generously across the globe, it is even more difficult to pin down exactly the nature of the focus of the $\mathrm{CSR}^{20}$ movement. It is clear that it is concerned with behaviour which it

17 Press release from DG Employment and Social Affairs and DG Enterprise and Information Society on launch of Green Paper.

18 See further COM (2005) 24 /final Working Together For Growth and Jobs: A New Start For The Lisbon Strategy: Communication from President Barroso in agreement with the Vice-President Verheugen. COM (2005) 330 final entitled Common Actions for Growth and Employment: The Community Lisbon Programme.

19 Supra n.16, para.2.

20 World Bank Report: 'Strengthening implementation of Corporate Social Responsibility in Global Supply Chain', 2003. The difficulties of establishing the truth which lies between real working conditions and reported working conditions is illustrated in many reports from organisations such as Fairtrade. See www.fairtrade.org. See Chap.3 Time to Play Fair regarding abuses in the sportswear industry. Even though corporate social responsibility movements can highlight the need to improve matters and abuses which take place, it is clear even from these kind of reports that there are aspirations to ensure that ILO labour standards are complied with, that governments in these countries comply by enacting legislation reflecting these standards and that in particular trade unions 
views as beyond mere compliance with regulatory norms. But as we have seen many of the proponents of CSR are not clear about the role of law in this endeavour, nor is it clearly acknowledged within CSR discourse that many types of behaviour which are considered responsible are also legally required. (The law is no stranger to responsibility!) Many within the CSR movement are also not clear as to whether these voluntary responsible corporate actions are a precursor to legal regulation or whether encouraging such behaviour should be regarded as a substitute to legal regulation. At least the EU documents are clear about this latter point and reiterate that CSR is not a substitute for regulation.

"Some may see the rapid development of codes as a dangerous trend towards a "privatisation" of social rights.

Clearly, codes can only complement and not replace national and international legislation or social dialogue and collective bargaining." 21

A further point can be made regarding CSR which is very clear from EU documents and that is the importance of CSR in the context of globalisation. It is primarily in relation to developing countries that the EU seeks to extend the CSR influence, but here two preliminary critical points can be made. Firstly, although addressing a global context, EU documents fail to recognise that most of the world's regulatory environments in the area of labour rights and environmental standards are a lot more flexible than that of Europe. Here we can distinguish between developed economies and others. In the developed world, outside of the European Union, the United States, in the area of employment and labour rights presents an entirely different picture from Europe. ${ }^{22}$ Canada and Australia present broadly similar pictures to the European one, but Japanese employment structures seem to work on a voluntary rather than regulatory basis. ${ }^{23}$ In many other less developed countries the level of protections afforded to European workers is unheard of, presenting therefore questions regarding the naivety of statements described in the Green Paper. Secondly, references are made to incorporation of ILO standards and other international standards without addressing whether this is practical in the short term or addressing the possibility that non-compliance with acceptable labour standards for example could be addressed closer to home.

The distinctions made between legal regulation and CSR encapsulated in the idea that CSR goes beyond legal compliance and represents an investment in human capital and sustainability which may yield competitive benefits resonates with the more theoretical school of thought on corporate action, the school which explores the potential of non legally enforceable norms as a way of regulating corporate behaviour. Norms scholars who have turned to

are permitted to act on behalf of indigenous workers. This represents some challenges to companies seeking low-cost manufacturing locations.

21 Supra, n.16 para.1.3.

22 Lynch-Fannon. Working Within Two Kinds of Capitalism. (2003). Freeman. Working Under Different Rules. (1994). Note that the EU ABC document supra n.16 refers to transatlantic meetings on core labour standards in relation to improving work standards in developing countries. Supra, n.16 p.9.

23 Learmount. Corporate Governance, What can be learned from Japan? (2002). 
corporate governance matters, hypothesise that corporate law principles and rules are designed to facilitate behaviour which is largely governed by non legally enforceable norms and that in reality in many corporate governance systems NLERS play very significant role in governing corporate action. However, as we will see in the final section most norm scholarship is concerned with "maintream corporate governance" in other words the relationship between the corporation, the management and the shareholders. It does not in general address CSR issues, but this article will seek to place CSR within this paradigm. For the moment however it is interesting to note that one of the most prominent US corporate governance scholars identified Scandinavian countries as possessing corporate governance systems where NLERS play highly significant roles. Coffee hypothesises by that in very competitive countries such as the Scandinavian countries NLERs are important and goes on to make assertions regarding the relationship between regulation or lack of regulation and competitiveness which are unfortunately unsupported by the evidence. Nevertheless the identification of reference to norms within the Scandinavian experience is not misplaced and indeed this would seem to reflect the European experience where it is acknowledged that the influence of Scandinavian thinking on competitiveness matters has influenced further development of the European Social model of corporate governance. $^{24}$

\section{Conclusion}

In conclusion of this part, a definition of CSR therefore can immediately clarify that CSR is focussed on non-legally regulated behaviour. It seems to be by and large focussed also with concerns regarding non shareholding stakeholders, such as communities, in particular global communities, workers, environment, consumers and so forth. Central to our understanding of CSR, both in terms of what it is and what it is not, is a clear articulation of it relationship to legally enforced standards. Unfortunately this question seems to generate a number of different approaches. CSR is seen by some as a step towards standards which will eventually be regulated. This is where we could regard the EU approach in a general sense. ${ }^{25}$ Others see CSR as

${ }^{24}$ For a description of the Scandinavian influence on the development of the Social Policy see further Lynch-Fannon. "The European Social Model of Corporate Governance: Prospects for Success in an Enlarged Europe" in Ali et al (Eds.) International Corporate Governance after Sarbanes-Oxley (2006), pp.423-443.

25 Some of the major steps in the EU approach to CSR matters are described chronologically below. The approach is characterised by a willingness to take steps in converting voluntary corporate action into matters of public record through accounting disclosure. Measurement and accountability thus become integral to CSR actions, converting purely private voluntary corporate action to a matter of public record and dialogue.

On 27 October 2004, the European Commission adopted a proposal for a Directive concerning annual accounts. This Directive proposal (COM(2004) 725) indicates that EU-based listed companies must disclose an annual corporate governance statement as part of their annual report. The Directive also indicates that within their corporate governance statement and where relevant, companies may also provide an analysis of environmental and social aspects necessary to understand their development, performance and position. While not mandating reporting on 
perhaps an anitidote to over-regulation. It is possible that the majority of those currently writing as norm scholars within corporate law scholarship are in this camp. Others see CSR as providing a feel-good factor in relation to how our corporations act in the world, this seems to have caught the populist imagination but also has caught the imagination of our marketing gurus. Unfortunately the latter two statements resonate with cynicism to which the author readily admits, but it is hard to see how from a lawyer's perspective this approach has any other meaning. However, on a more positive note, it is acknowledged that it is important not to be totally dismissive particularly when one considers the good work of lobby groups such as the Fairtrade movement and in the US the Domini group www.domini.com which has been active as a socially responsible funds investor in the retail clothing sector. It is important to try to focus on the question of what CSR can deliver that law is not delivering and to consider how both can compliment each other rather than compete.

\section{Part II: The Courts and the Legislature.}

This section seeks to provide the reader with some illustration of how the legal regulation of companies will find a place for CSR. Legal regulation will include judicial statements in decided cases and statutory material. The section also aims to clearly articulate the legal basis and theory underlying

CSR issues, the Directive recognizes the relevance of environmental and social issues in the context of corporate governance. http://europa.eu.int/comm/internal _market/accounting/otherdocs_en.htm. In its communication entitled 'Corporate social responsibility: a business contribution to sustainable development', $\operatorname{COM}(2002) 347$, the Commission invited the European Multistakeholder Forum on CSR to develop commonly agreed guidelines and criteria for measurement, reporting and assurance by mid-2004. The CSR Forum presented the Commission a final report with its conclusions on 30 June 2004. http://forum.europa.eu.int/irc/empl/csr_eu_multi_stakeholder_forum/info/data/en/ CSR\%20Forum\%20final\%20report.pdf .

The Forum has pursued a relatively active agenda and its latest meetings in December have been referred to above. Supra n.15. In its Report on The Commission Green Paper on promoting a European framework for corporate social responsibility, the European Parliament has invited the Commission to bring forward a proposal on the appropriate directive (the fourth company law directive) for social and environmental reporting to be include alongside financial reporting requirements. In its Communication On The EU Strategy For Sustainable Development, $\operatorname{COM}(2001) 264$, the Commission invited all publicly quoted companies with at least 500 staff to publish a 'triple bottom line' in their annual reports to shareholders that measures their performance against economic, environmental and social criteria. In 1998, the High-Level Group on Economic and Social Implications of Industrial Change set-up at the invitation of the European Council, invited companies of more than 1,000 employees to publish voluntarily a 'Managing change report', i.e. an annual report on employment and working conditions (e.g. employee consultation and social dialogue, education and training, health and safety, equal opportunities) to be developed in consultation with employees and their representatives in accordance with national traditions. See further $\mathrm{ABC}$ of the main instruments of Corporate Social Responsibility referred to at supra n.16. 
the limited liability corporation and to identify a proper role for voluntary behaviour aimed at non shareholder, stakeholder welfare.

The chancery courts have always considered managerial activity in an expansive way. There has always been room for what is now described by some as CSR ever since Lord Hutton recognised that, "The law does not say that there are to be no cakes and ale, but there are to be no cakes and ale except such as are required for the benefit of the company. .."26 It is of course important that generosity and responsible action within the paradigm of company law must be linked to the overall prosperity of the company and this is equally true in modern discourse on CSR where different kinds of justifications for adoption of CSR policies are inevitably linked to corporate benefit. It may sound harsh to point this out but in reality both legally and theoretically it would be unacceptable to propose any thing else. In other words it would be unacceptable to present the corporation as a vehicle for achieving any sort of broad based social goods which were not referred back to the primary function of the corporation, to make money and profits for its shareholders. The argument here is that corporate law has already understood this. Many cases grapple with this balancing act. The famous US case of Shlensky v Wrigley ${ }^{27}$ which involved a shareholder action alleging that the directors and in particular the defendant were delinquent in not installing lights to facilitate night games of baseball recognised that the directors of a company who exercise the legitimately delegated power of the shareholders will not be subject to the control of the courts over decisions which are discretionary in nature as to the direction of the business. This is the case even if other decisions may be demonstrably wiser or may render the business more successful or profitable. The plaintiff had alleged that the directors were dominated by the defendant majority shareholder's view that baseball was a "daytime sport" and that installing lights would affect the character of the surrounding neighbourhood. The court speculated that perhaps a long term view of the value of the property might have motivated this refusal but more importantly emphasised that the court's role was not to second guess management decisions: "Directors are elected for their business capabilities and judgment and the courts cannot require them to forego their judgement because of the decisions of directors of other companies. The court reiterated that for it to decide that a decision of the directors was a correct one is "beyond its jurisdiction and ability. We are merely saying that the decision is one properly before the directors and the motives alleged in the amended complaint showed no fraud, illegality or conflict of interest in their making of that decision." 28 Similarly on this side of the Atlantic, in Howard Smith Ltd v Ampol Petroleum Ltd ${ }^{29}$ the court stated that it will "necessarily give credit to the bona fide opinion of the directors, if such is found to exist, and will respect their judgment as to matters of management; having done this, the ultimate conclusion has to be as to the side of a fairly broad line on which the case falls." On the other hand in Dodge v Ford

26 Hutton v West Cork Rwy Co. (1883) 23 Ch. D. 654, 672.

27 Shlensky v Wrigley et al 95 Ill. App. 2d 173; 237 N.E. 2d 776; 1968 Ill. App. LEXIS 1107.

28 See further M Dooley, Fundamentals of Corporation Law (New York, The Foundation Press, 1995), 206-210.

29 [1974] AC 821, 835, 
Motor $\mathrm{Co}^{30}$ the court was of the view that the socially altruistic desire of Henry Ford to invest all company profits in making the cheapest cars to make cars generally available to the American public and to generate more quality jobs in the community had to be balanced fairly against the interests of the shareholders who sought some distribution of the profits as dividends. The court expressed the view that the re-investment of all profits was "not only far from related to the good of stockholders, but amounted to a change in the ends of the corporation and that this was not a purpose contemplated or allowed by the corporate charter." Accordingly, the plaintiff who owned $10 \%$ of the stock in the Ford Motor Co. successfully obtained an order that some of the corporate profits would be paid in dividends, but was unsuccessful in enjoining the company from further expansion as the court was of the view that it could not interfere with the decision of the directors to expand the business, stating that "The judges are not business experts." 31

Many cases illustrate quite clearly the understanding that altruistic and responsible behaviour can benefit the company and its shareholders, but on the other hand the Ford Motor Case illustrates that the courts are also mindful of the basic tenets of company law and corporate law theory, namely that the company is ultimately there for the benefit of its shareholders and other goals can only be pursued through this prism. Interestingly the courts draw a rather stringent line in relation to altruistic behaviour when the company is insolvent and approaching liquidation. In these cases the courts indicate that at this point in a company's life it is too late for this kind of largesse, the point being that an insolvent company has nothing to gain and disbursement of funds should be curtailed so that as much as possible is available to creditors. ${ }^{32}$ The courts have long recognised that the imposition of directors legal liability and duties are not amenable to application of broadly similar rules across the board. The law allows for entrepreneurial and managerial behaviour. It supports the concept of risk taking. The rule in Smith (Howard) Ltd v Ampol Petroleum Ltd. ${ }^{33}$ states that "it would be wrong for the court to substitute its opinion for that of the management, or indeed to question the correctness of the management's decision ... if bona fide arrived at. There is no appeal on merits from management decisions to courts of law: nor will courts of law assume to act as a kind of supervisory board over decisions within the powers of management honestly arrived at."

In the US this approach has been characterised as the business judgement rule and is more highly articulated as it has become very significant in litigation regarding takeovers and mergers ${ }^{34}$ but it has always been important regarding a whole range of decisions by managers regarding corporate actions, such as those exemplified in Shlensky and indeed in Dodge. The

30204 Mich. 459; 170 NW 668.

31 ibid., p.684.

32 Parke v Daily News Ltd [1962] Ch. 927 where gratuitous payments to employees at the end of a company's life were overturned by J. Plowman even though most shareholders supported the initiative. This could not be for the benefit of the company at this point as there was no reputational gain. See also $R e \mathrm{~W} \& \mathrm{M}$ Roith [1967] 1 W.L.R. 432. Re Horsely \& Weight Ltd. [1982] 3 All.E.R. 1045. See also Russell Kinsela etc. regarding creditors.

33 [1974] A.C. 821, 831.

34 Smith v Van Gorkom Time Paramount etc. 
standard for review of business decisions in the US is now contained in section 102(b)(7) of the Delaware Corporate Code which was enacted after the response to the court's decision in Smith v Van Gorkom $^{35}$ and requires that there must be "a showing of fraud, illegality or conflict of interest." The legal framework which imposes a broadranging duty of care and loyalty on corporate managers also protects them from liability for mistaken decisions or decisions which might not always directly benefit the shareholder wealth maximisation principle as long as these decisions are made in good faith. Thus in most cases shareholders cannot insist on short term profit maximisation at the expense of long term decisions which will benefit the company in different ways. Decisions to support workers, communities, customers and so forth all come within this subset of decisions, they are unassailable in the corporate law paradigm and in fact are actually encouraged through many examples of judicial rhetoric, support for managerial discretion protects directors who want to act in socially responsible ways.

However, there are limits to this rosy picture and this is particularly the case in a category of cases where employees interests as stakeholders directly conflict with the rights of shareholders as residual claimants and also with the rights of creditors. These cases have a common strand and that is that they address this conflict in the context of insolvency or more broadly speaking in cases where corporate coffers are not flowing and the money is tight. Thus in Parke v Daily News Ltd..$^{36}$ the courts could not countenance ex gratia payments to employees, in the Irish case of $R e$ Frederick Inns ${ }^{37}$, the courts could not allow funds from one company to be used to pay creditors of another. In Yongstown Ohio the courts tried to grapple with the worst case scenario where a company removes itself from a community but could find no legal principles where it could restrain a company from doing so. It is difficult to see how a court could cut across this fundamental principle which allows for capital mobility. ${ }^{38}$

A theoretical limitation which clouds existing legal support for socially responsible managerial action emanates from the emphasis on capital market

35 Smith v Van Gorkom, 488 A. 2 d. 858 (Del. 1985).

36 [1962] Ch. 297.

37 Interestingly in both these cases the somewhat harsh effect of the decision has been reversed by legislative provisions. See Companies Act (Ireland) 1990, s.52 and Companies Act 1985, s.309(1). See further Sealy, Cases and Materials in Company Law (1996), 281-82. Similar statutes exist in some American jurisdictions. For a general discussion see M. O'Connor, "Corporate MalaiseStakeholder Statutes: Cause or Cure?" (1991) 21 Stetson Law Review 3. EW Orts, "Beyond Shareholders: Interpreting Corporate Constituency Statutes" (1992) 61 George Washington Law Review 26.In all cases the effect of the legislative provisions is that managers are now explicitly permitted to consider the welfare of employees as stakeholders, but not mandated to do so, nor are there any clear rules as to how the differing interests of employees as stakeholders which might conflict with shareholders' interest can be resolved. See futher Lynch-Fannon Working Within Two Kinds of Capitalism (2003). Interestingly the regulatory landscape has also imposed extensive obligations in relation to plant closure at European level leading Mark Roe to famously comment regarding his experience with German restructuring, that "these companies really care about their people."

38 US States Steelworkers v United States Steel 631 F. 2 d. 1264 (6 $6^{\text {th }}$ Cir. 1980). 
responsiveness. This will be considered below. Another interesting area where the courts have again identified the importance of legal discourse in the CSR context is represented by the US case of Nike $\mathrm{v}$ Kasky regarding the ability of Nike Inc to engage in public debate regarding allegations made against it about its use of sweatshop labour. Although settled, the judiciary were conscious of this important social activity and the dissenting judgement of J. Kennedy in noting the public interest in a public debate on corporate activity rightly identified the role of the courts in encouraging corporate involvement in this debate. Over all however, the Nike story isn't good because it highlights how difficult it is for CSR alone to achieve desirable goals.

Apart from cases on director's duties which have been developed over time in many jurisdictions, different kinds of regulation has developed in recent years which has been derived from statutes. ${ }^{39}$ Under these statutes the courts have also grappled with the standard of risk taking which they consider acceptable within the modern regulatory legislative framework exemplified by legislation providing for directors disqualification and restriction. ${ }^{40}$ This legislation introduced in all three jurisdictions of United Kingdom, Northern Ireland and Republic of Ireland in the late 1980s and 1990 has received quite a bit of judicial attention. This legislation is particularly directed at the protection of non-shareholding stakeholders such as creditors and to some extent employees, although of course shareholders will also benefit from the standards imposed. However a hypothesis proffered in this article is that even though rhetorically the legislation aspires to imposing higher standards of behaviour than those already imposed in the common law, the courts are still immersed in the culture of non interference and respect for risk taking. (Not entirely a bad thing!) The judgment of J. Peart in Re USIT World plc ${ }^{41}$ is infused with respect for the exciting life of the entrepreneurial risk-taker and the contribution he or she makes to our world.

"A risk taken against such a background of planning and knowledge, and with appropriate advice taken, might be reasonably characterised as a calculated risk without any element of carelessness, rashness or recklessness attached to it which could attract the tag of irresponsibility. Clearly the greater the amount of money involved in the risk the greater is the obligation on all concerned to ensure that appropriate care is taken in all aspects of its planning, so that all factors, reasonably foreseeable, which may cause the venture to fail, will be anticipated and guarded against.

39 Note, Norman Veasey has remarked in relation to the extending of Federal legislation in the US with the introduction of the Sarbanes Oxley Act that this will bring in a development of corporate law away from litigation over fiduciary duties to a focus 'on litigation going after officers as the actors in fraud cases'. See Veasey N: 'The Judiciary's Contribution to the Reform of Corporate Governance' [2004] JCLS 225. This is even more likely on this side of the Atlantic because of the difficulty of mounting shareholder actions against management as distinct from the US.

40 See Company Directors Disqualification Act (UK) 1986. Part V 1990 Companies Act (ROI) as amended by Company Law Enforcement Act 2001 (ROI).

41 [2005] IEHC 285. 
If an entrepreneur were to be obliged, on pain of being found irresponsible and of being restricted under the section, to avoid taking any decision which at some date in the future might be found to have risk attached to it, the business life and a large component of the economic driver of the economy of the State would stultify. I do not believe that this is what the legislature had in mind when enacting section 150."

\section{Conclusion}

All corporate regulation must be justified by reference to some developed corporate law theory regarding the function of the corporation, the role of its management and the role of shareholders. Thus in Allen's analysis some years ago of the debate between the European model and the US model of corporate governance concerning non-shareholding stakeholders he referred to the "managerialist" conception of the corporation, a view of corporate function which is both more pragmatic and more predominant in reality than either the communitarian or contractarian approaches which he also describes. The managerialist view is the theory which best fits what Allen describes as managerial practise in most corporations and the judiciary's understanding of corporate function, both of which he had occasion to understand as Chancellor of the Delaware Court. ${ }^{42}$ The cases referred to in this section reflect this more pragmatic approach. In the context of CSR the principle of shareholder primacy as distinct from shareholder wealth maximisation is the constraining principle. Corporate law theorists have recognised that the current emphasis on short termism has threatened responsible corporate action. Perhaps this is why we have had a concurrent growth in the CSR movement. For example, Laurence Mitchell has asked us whether Wealth is a Value ${ }^{43}$ echoing the concerns expressed by Dworkin in the mid $80 \mathrm{~s}$ as the law and economics school of thought reached an ascendancy in Chicago and beyond. ${ }^{44}$ Mitchell deplores the growth in corporate irresponsibility, particularly in the context of globalisation, and wonders whether from an ethical perspective wealth can be pursued as a free-standing value. David Millon has usefully distinguished shareholder primacy and shareholder wealth maximisation. ${ }^{45}$ The argument is that acceptance of orthodox corporate law theory which places shareholder primacy at the centre does not necessarily imply a slavish loyalty to shareholder wealth maximisation at all costs. This point must be emphasised in light of misunderstandings as to what is meant by shareholder primacy or shareholder value. In a commentary on Lawrence Mitchell's Corporate Irresponsibility, ${ }^{46}$ Millon considers the issues identified by Mitchell surrounding current management practices in corporate America. In

42 Allen, "Contracts and Communities" (1993) 50 Washington and Lee Law Review 1. The discussion of Allen's views and quotations are all derived from this article. See also Lynch-Fannon. Working Within Two Kinds of Capitalism (2003) and Lynch-Fannon. 'Employees as Corporate Stakeholders: Theory and Reality in a Transatlantic Context.' 4 Journal of Corporate Law Studies 155 (2004).

43 Mitchell. Corporate Irresponsibility: America's Newest Export (2001). Chap.4.

44 Dworkin. Is Wealth A Value? 9 J. Leg. Stud. 191 (1980) reprinted in A Matter of Principle.

45 Millon, "Why is Corporate Management Obsessed with Quarterly Earnings and What Should be Done about It?" (2002) 70 George Washington Law Review 890

46 Supra. n.43. 
particular, the pressure felt by management to maximise shareholder profit, which Millon describes as "the SPM" goal, (shareholder profit maximisation) is considered. In his work the SPM goal is clearly separated out from other concepts that are central to our understanding of corporate function. Millon makes it clear that in his understanding of Mitchell's work SPM can be "condemned without embracing a corporate social responsibility agenda ..." which Millon views as being too radical. The importance of this point is quite simply that rejecting SPM is not necessarily a radical step or as radical a step, for example, as the adoption of a corporate responsibility theory which might well go so far as to require the acceptance of equal claims to corporate wealth for other constituencies such as employees, creditors, and community interests in environmental welfare. Millon's understanding of corporate social responsibility is perhaps overstated. What is important is the view that rejecting the current SPM modus operandi is or could be acceptable to a broad range of corporate law theorists. Thus, as we have seen the courts on both sides of the Atlantic have always tolerated a wide area of managerial discretion under some version of the business judgement rule. Company law principles and the cases derived from these principles clearly illustrate that shareholder wealth maximisation is not a goal that must be pursued with short term ruthlessness and that, in fact, many management decisions, for example, relating to spending what would otherwise be distributable profits on advertising, political contributions, sporting and cultural events and philanthropic donations, have always been protected by the courts. As we have seen, even in the dark ages of the early nineteenth century it was recognised that some benefits, in this case, cakes and ale for the employees might bring benefits to the company in terms of performance incentives! The broad discretion given to management under fiduciary duty principles underlines the point similarly. In common law jurisdictions which have enacted "other stakeholder statutes", it is clearly indicated that a slavish adherence to shareholder wealth maximisation is not required. In summary, therefore, these statutes, together with judicial pronouncements in common law jurisdictions in relation to managerial discretion, acknowledge that although orthodox corporate law theory continues to support shareholder primacy (shareholder value), shareholder wealth maximisation, particularly the ruthless pursuit of short-term shareholder wealth, is neither required nor necessarily desirable.

Thus an alternative approach to corporate irresponsibility is presented in this article relying on two responses;

Firstly, a return to the realisation that the courts have always expected higher standards from managers beyond mere profit maximisation at all costs. A consequent emphasis on judicial guidelines on the role of directors and further analysis of judicial thought in this area is important.

Secondly an acceptance of the idea that the legislatures of jurisdictions in which most international companies reside, in addition to international institutions have a regulatory role to play in setting standards.

\section{Part III: Corporate Law Theory and Norm Scholarship.}

Contemporaneously in the United States we have seen a growth in scholarship in the role of norms in corporate governance. As interest in norms grew in the arena of corporate law scholarship a distinction was made, 
pioneered by Rock and Wachter ${ }^{47}$ between legally enforceable company law rules and NLERS, non-legally enforceable rules and standards and whilst admitting the inelegance of NLERS they chose this term to clarify the voluntary nature of the norms with which we are concerned, representing a context where behaviour is adhered to through a privately enforced system of rewards and penalties. They argue furthermore, athough not central to the points made here, that if enforcement includes even "a judicial backstop" 48 the agreement in relation to certain kinds of behaviour is legally enforceable. But nevertheless despite their claim regarding the presence of the "judicial backstop" and the impact on whether a standard is legally enforceable or not, Rock and Wachter also claim that "important parts of corporate law can be understood as establishing a structure within which non-legally enforced self-governance can thrive." ${ }^{\prime \prime} 9$ On the whole the majority of corporate governance scholars recognise the connection between good behaviour towards stakeholders to whom no legal duty is owed, for example employees expecting Christmas gifts, communities expecting arts and cultural sponsorship and the fulfilment of the shareholder primacy obligation required in corporate law and the role the courts have placed in guiding the way. That said much of the norm scholarship in the context of corporate governance focuses almost exclusively on the director-corporationshareholder relationship and on the facilitating role of corporate law in guiding good managerial behaviour towards shareholders. ${ }^{50}$ At least we can all agree with Rock and Wachter when they propose that "the structure of corporate law, whether embodied in statute or case law, is more fully understood if the effects of norm governance are included in the analysis."

\section{The Influence of Norm Scholarship.}

There are essentially two kinds of norms scholars. Firstly, there are those who identify norms as standards of behaviour which are not legally enforceable but which inform in some cases the exposition and articulation of legal standards. This is a very apt analysis when we consider many decisions from a number of jurisdictions where the courts have traditionally expounded and considered issues at the edge of corporate law pathology. ${ }^{51}$ The second kind of norm scholar is one who seeks a broader definition of non legally enforceable norms developed in more recent times. This kind of norm scholar seeks to embrace the CSR movement. Here a school of thought puts forward the idea that norms will yield behaviour which is desirable but which it is argued law cannot and perhaps ought not deliver. This is a more difficult proposition.

The first kind of norm scholar will agree with the proposition that when one considers many judicial comments over the years, it is clear the courts have always embraced and understood that law will and can deliver very high

47 University of Pennsylvania Symposium: Norms and Corporate Law, supra n.9.

48 ibid., 1613.

49 ibid., 1611.

50 See Veasey, supra n.39 for summary.

51 Prentice, D: "Some Observations on the Teaching of Company Law", coined this phrase in describing the company law undergraduate syllabus in Birks, $\mathrm{PBH}$ : Examining the Law Syllabus: Beyond the Core (Oxford University Press, Oxford, 1993). 
standards of managerial behaviour. Here norms which describe more fully principles of good faith, loyalty, ${ }^{52}$ risk taking which is not reasonable or honest, impose upon corporate directors and management broad ranging obligations not always easy to grasp for the ordinary business person but which are very familiar to corporate lawyers. The difficult question for norms scholars in about process, how exactly does this work and what do the judges think they are doing? Having established the conceptual framework for asking the very important question as to what is going on when the courts attempt to deal with aspirational norms such as loyalty, and good faith but back away from enforcing liability for possible infringement of the rules, Rock and Wachter fail to make sense of the answer. They allow that the legal principle presents us with an undemanding standard of conduct, but also acknowledge that judges spend a lot of time considering these cases even though they, the judges, reiterate the business judgement rule as a jurisdictional boundary. ${ }^{53}$ In their explanation they end up treating as exceptions two US cases where directors were reprimanded. Here however, it is argued that Rock and Wachter have reversed the analysis and laid the emphasis in the wrong place. As stated in the previous section, the courts have always understood and protected the director who is not focussed on shareholder wealth maximisation, i.e. the director who acknowledges the primacy of the shareholder but also recognises the importance of other stakeholders. The function of rules which protect managerial discretion allow directors to mediate in this way between competing claims. The function of the courts is to fill out the expansive nature of this protection and that is where the rhetoric contributes in an important way as Johnson mentioned. Shareholders wealth does not have to be attained at all costs. The only situation where the law will intervene to protect shareholders at all times is where the directors are themselves trying to benefit. ${ }^{54}$

\section{The Second School of Norms and What It Has To Do With The Dark Side of CSR.}

Broadly speaking CSR will consist of a body of non-legally enforceable norms of good behaviour, for example pro-active environmental actions, community activism and other kinds of actions which will deliver beneficial results. However, it is clear that all CSR initiatives must be viewed within the currently understood paradigm of corporate function as expressed in corporate law and theory. Therefore shareholder primacy will and must guide all norm driven behaviour. In this context it is useful to ask why any corporation which is not legally obliged to do so would embrace CSR in any of its guises. The justifications must be inherent in our understanding of the purpose of the corporation that is shareholder wealth creation. The only way any CSR initiative can be justified is because it is financially beneficial to the company and consequently its shareholders. The benefit to the shareholders

52 Johnson, L: “After Enron: Remembering Loyalty Discourse in Corporate Law” 28 Delaware Journal of Corporate Law (2003) 27.

53 Rock and Wachter: "Islands of Conscious Power: Law, Norms and the SelfGoverning Corporation" 149 University of Pennsylvania Law Review (2001) p.1699.

54 ibid. 1696. 
can be described in public relations terms broadly speaking. This is not a cynical point. Many companies involved in CSR will state that it is good to be viewed as a good corporate citizen, to get the accolade of one of the best companies to work for ${ }^{55}$ or to be known for example as a company which is involved in environmental protection initiatives, ${ }^{56}$ or to be known as a company which protects the integrity of its supply chain. ${ }^{57}$ This point also recognises that if good corporate citizenship is a response to populist demands for corporate social responsibility well that is a good thing too, insofar as it goes.

However a more unsavoury aspect to the push to advance CSR is the argument that CSR is good for companies and shareholders because it keeps governments and regulators at bay. CSR presents an attractive alternative to regulation. Regulation and law is viewed as hostile to business interests, enforcing non-voluntary standards that corporations will not accept. In a nutshell this is the part of CSR which prefers for example "family-friendly" policies to hard-core regulation, the approach currently favoured in the United States to balancing work and family which is so different to the European approach. It is a movement, perhaps more gravely, which prefers voluntary environmental measures to the Kyoto agreement and which would prefer initiatives in relation to their own workers in developing countries rather than support implementation of ILO standards. What is most worrying is that CSR will be hijacked in this way by those who want to keep the regulators away, reflecting what Chomsky has described as the "American passion for de-regulation"58 a passion which reached its zenith of achievement in the late 1990s but perhaps is on the decline slightly since Sarbanes-Oxley ${ }^{59}$ was passed. But here we find resonance with the rise in norm scholarship, with many norms scholars making such robust arguments for the facilitative role of company law that one can only conclude that the agenda is to resist further Federal or state regulation rather than explore the relationship between norms, corporate laws and good outcomes in any genuine way. For example, Coffee states that the idea that corporate behaviour "may be more shaped and determined by social norms than by legal rule seems to an idea whose time has come". ${ }^{60}$ This may well be true in a socially descriptive way but note that he does not shy away from the prescriptive position and goes on to state that commentators "have placed the relative efficacy of social norms as compared with legal rules at the centre of the debate over the judicial role in corporate law" and also notes the arguments that perhaps the courts should be less rigorous because social

55 Continental Airlines '100 Best Companies to Work For' Fortune Magazine 19982004. www.continental.com.

56 ShellBP has its own 'Environment and Society' website. www.shell.com. Interface Inc. is the world's largest manufacturer of carpet for use in offices and other public spaces. It has a website devoted to sustainable development at http://www.interfaceinc.com/goals/sustainability_overview.html, accessed January 2007.

${ }^{57}$ Gap Incorporated.http://www.gapinc.com/public/SocialResponsibility/sr_factories. Shtml.

58 http://www.zmag.org/zmag/articles/may97chomsky.html.

59 Sarbanes-Oxley Act 2002.

60 Coffee: "Do Norms Matter? A Cross-Country Evaluation" 149 University of Pennsylvania Law Review 2151 (2001). 
norms adequately govern behaviour. In testing these hypotheses out Coffee quite peculiarly identifies the Scandinavian countries as areas where norms seem to place an important role, but fails to acknowledge the equally if not more important fact of Scandinavian countries present a very highly regulated environment, particularly as regards the interests of nonshareholding stakeholders. Norman Veasey similarly decries further attempts at Federal regulation as exemplified by Sarbanes Oxley and argues that norms have operated quite well against the backdrop of the common law, again seeming to advocate a hands off approach for the statutory regulators. In conclusion of this part then two cautionary notes must be sounded. The first is that nonlegally enforceable norms will not yield uniform responses to issues which matter to us. Even though CSR can play a part in engaging in discourse with companies which might perceive an advantage in acting in a voluntary way, legal standards must articulate what is desirable for all. Law cannot it is argued be viewed as a minimum paving the way for responsible and socially altruistic behaviour, the function of law is to yield high standards in its own right through high legislative standards, effective enforcement and penalties. The second is the danger that the CSR movement will be hijacked by those who favour voluntarism in a cynical way. Those who are descendants of the law and economics school of thought who see again a theoretical argument for resisting what they consider to be "big government." Both of these dangers are interrelated. If CSR is used as a way of fending off "big" government or if CSR is advocated as the only way a particular problem can be solved we will find ourselves stuck in a mindset where our failure to address problems will be regarded with considerable shock and dismay by future generations.

\section{Conclusion}

As indicated in the previous section directors and managers of corporations have experienced increased pressure to maximise shareholder wealth in a short term way. In turn this pressure has derived support and impetus from those in the corporate governance movement who placed such emphasis on capital markets theory as the most appropriate governance and monitoring device. We can now accept that despite theoretical assertions of the market as the most efficient of governance devices which dominated literature in the late 1980s and 1990s, these theoretical descriptions did not and do not account for flaws in how the market operates in reality. Recently, informational asymmetries, including not least, the failure of analysts to act independently of each other, and recent revelations in relation to the shortcomings of auditing practices ${ }^{61}$ clearly illustrate the discrepancies between market value of shares and actual corporate performance. All of these events tend to support those (including this author) who have argued that although markets do function reasonably accurately, particularly in relation to established companies, they are not transparent and are not without flaws. It is in fact these corporate scandals which have prompted a wider group of scholars beyond those who were never convinced about the

${ }^{61}$ For a very interesting description of the variation in auditing practices on both sides of the Atlantic and the difference this can make to the financial statement of particular companies see: G Meeks, "Reporting to Shareholders: The Proposals in the Company Law Review" (2003) 3 Journal of Corporate Law Studies 191. 
capital markets theory in the first place, to revisit issues such as corporate responsibility, shareholder wealth maximisation and so forth. ${ }^{62}$ The DTI's consideration of competing views of corporate function concludes quite clearly (and correctly) that "shareholder value" is the primary principle which has been and will continue to be pursued by the company law regime. ${ }^{63}$ The shareholder value principle can be equated with shareholder primacy. Whilst embracing shareholder value or shareholder primacy principles we can recognize that this does not imply a rejection of all stake holding claims and conversely recognition of the reality of stakeholders' claims does not imply a negation of the central capitalist principle of shareholder value or primacy. All that is required is a recognition of the possibility of balance and that government and regulation have a role in arriving at this balance.

"One underlying imperative exists and that is the acceptance that the corporation is indeed a public actor in relation to employee welfare issues. As such the corporation is subject to government regulation in pursuit of goals which may have little immediate effect on generating wealth for shareholders, but much to do with striking a desirable balance between this goal and the broader concerns of government and society."

The resolution of this distinction allows for the embracing of a different understanding of corporate function which is more nuanced than a simple shareholder wealth maximisation model. For example it will easily embrace the European Social Model of corporate governance which though clearly capitalist and shareholder driven also recognizes the importance of other stakeholders including employees and creditors, and the importance of locating the company within its societal context. Thus there is no contradiction between shareholder primacy and the Lisbon goal of regulating the corporation as one social element in achieving the goal of creating for the future "a dynamic knowledge based economy capable of sustainable economic growth with more and better jobs and greater social cohesion." Quite clearly this resolution will also allow us to contemplate a legitimate place for CSR, but this will always be within the existing corporate law paradigm. . .

Finally, it is also important to emphasise that whilst traditional corporate law theory views the various non-shareholding constituencies as being outside

62 Veasey N. supra n.39 for description of bubble or boom in 1990s and its cause and effect.

63 www.dt.gov.uk.

64 Lynch-Fannon, supra n.2, 133-34.

65 Supra n.95 and n.96. Understanding of the European goal of a knowledge based economy seems to resonate with Plender when he concludes that despite its supporters the "old model of capitalism" has "gone off the rails" and a new paradigm or set of rails must be found which "enable knowledge managers and workers to be incorporated into the corporate governance process. That points more in the direction of something akin to the currently unfashionable insider, or stakeholder, systems of capitalism, in which accountability is imposed by informed insiders rather than outside shareholders working through independent nonexecutive directors and a hostile takeover discipline.” See further: Plender, Going Off the Rails, Global Capital and the Crisis of Legitimacy (Chichester, John Wiley \& Sons Ltd, 2003) 264-70. 
the remit of corporate law, that does not by any means preclude an acceptance of the fact that these constituencies are entitled to protect their position or their entitlement to corporate wealth "either by the terms of their contracts with the corporation or by means of favourable regulatory legislation obtained through the political process." ${ }^{\text {"6 }}{ }^{6}$ Reference to the political process raises interesting questions regarding the acceptance of the recognition of other stakeholders in the corporation. In conclusion, adherence to shareholder primacy (or shareholder value) does not require that shareholder wealth is maximised in the short-term to such an extent that the accordance of corporate benefits to the community in the form of philanthropic activities or the distribution of some element of corporate wealth to stakeholders, for example employees have to be viewed continually against the demands of shareholder wealth maximisation, whether this is short-term or long-term or some odd and reflexive mixture of both. The costs entailed by giving benefits to employees do not have to be assessed crudely against shareholder wealth maximisation goals where certainly in the short-term view of wealth maximisation it will not make sense to be socially responsible. Good managers have always understood that distributing some share of corporate wealth to employees in terms of good working conditions and to the community in terms of involvement makes a lot of sense in terms of the long-term generation of wealth for the corporation and its shareholders. This view has been described 67 as the "managerialist" understanding of corporate activity, which reflects an understanding that knowledgeable and experienced corporate managers have always tried to behave with a balance in mind between profit generation and long-term planning. It is also clear that corporate law and corporate finance theory understand how good managers behave and that the courts have supported their discretionary actions for decades.

Elsewhere this author has written about resistance to employment regulation in the US and how strange this is from a European perspective. What is most interesting is the hostility to European style regulation disguised as academic argument, hostility which is given real and pragmatic expression in the US through lack of labour market regulation. ${ }^{68}$ Now we are faced with many moral and ethical challenges presented to us by the demands of corporate and capital mobility. Is CSR the only response available to us? It is hoped that this is not that case and that law will recover her dominion and deliver mandated enforceable standards, even at a minimum level across the globe.

66 Millon, supra $\mathrm{n} .45$ at p.901.

67 Allen: W. T: "Contracts and Communities in Corporation Law". 50 Washington and Lee Law Review (1993).

68 I. Lynch-Fannon: supra n.2. 